\title{
Quantifying the influence of eucalyptus bark and corncob biochars on the physico-chemical properties of a tropical oxisol under two soil tillage modes
}

\author{
Boris Merlain Djousse Kanouo, ${ }^{1,2}$. Suzanne Edith Allaire ${ }^{3} \cdot$ Alison D. Munson $^{1}$
}

Received: 1 December 2018 / Accepted: 24 July 2019 / Published online: 8 August 2019

(c) The Author(s) 2019

\begin{abstract}
Purpose This study aimed to assess the impact of two biochars applied at the rate of $15 \mathrm{tha}^{-1}$ on physico-chemical parameters of an oxisol in Cameroon.

Methods The biochars were made from slow pyrolysis $\left(\sim 300^{\circ} \mathrm{C}, 4 \mathrm{~h}\right)$ of eucalyptus tree bark and corncobs and then incorporated into the top $15 \mathrm{~cm}$ of the soil with or without straw. The soil tillage mode was either flat plots or furrows and ridges. Soil porosity, bulk density, saturated hydraulic conductivity, available water content, $\mathrm{pH}$, nitrogen, potassium, phosphorus, cation exchange capacity and electrical conductivity were analysed before biochar application, then 6 and 12 months after. Results None of the measured soil physical parameters were affected by the presence or type of biochar. The total porosity was lower during the second production period compared to the first, while available water content and van Genuchten parameters increased during the second production period. No significant difference was observed between soil nitrogen, phosphorus, potassium, cation exchange capacity and electrical conductivity of control and treated plots.

Conclusion We recommend that straw be pyrolysed and the resulting biochar incorporated into soil instead of burying straw (as is actually done in furrow and ridges tillage mode).
\end{abstract}

Keywords Biochar $\cdot$ Oxisol $\cdot$ Soil physico-chemical parameters $\cdot$ Furrows and ridges tillage mode $\cdot$ Flat plots tillage mode

\section{Introduction}

Biochar is the porous carbonaceous solid produced by pyrolysis, i.e. thermochemical conversion of organic materials in an oxygen-depleted atmosphere. Its physico-chemical properties have potential to contribute to long-term storage of carbon in the soil and improvement of soil structure and fertility (Kimetu and Lehmann 2010). Biochars made from diverse biomass are characterized by different morphological and physico-chemical properties, and also differ based on

Boris Merlain Djousse Kanouo

djoussemerlain@gmail.com

1 Centre d'Étude de la Forêt, Département des sciences du bois et de la Forêt, Université Laval, 2405 rue de la Terrasse, Québec, QC G1V 0A6, Canada

2 Département du Génie Rural, Faculté d'Agronomie et des Sciences Agricoles, Université de Dschang, B.P. 222, Dschang, Cameroon

3 Centre de Recherche sur les Matériaux Renouvelables, Université Laval, Québec, QC G1V 0A6, Canada pyrolysis conditions, including temperature, rate and duration (Mukherjee et al. 2011; Butnan et al. 2015). Biochar has the potential to improve fertility of degraded soils either by direct supply of nutrients, by fixing nutrients followed by subsequent slow release or by improving soil structure and water retention (Unger et al. 2011).

In tropical areas such as in Cameroon, oxisols are among the dominant soil types. They are characterized by an acidic $\mathrm{pH}(3-5.5)$, high concentration of heavy metals, $\mathrm{Al}$ and Fe toxicities and low cation exchange capacity (CEC), all which limit plant nutrient availability, resulting in lower crop yield (Chintala et al. 2012). Organic and inorganic fertilizers could contribute to maintain or increase the fertility of these soils. However, under the economic conditions prevailing in many sub-Saharan African countries, resource-poor farmers use little chemical fertilizer (Craswell and Vlek 2013). In addition, benefits only last for a few growing seasons, since added nutrients are prone to leaching, given the low CEC of oxisols (Baligar and Bennett 1986). In these acidic soils, biochar has been shown to improve the holding capacity of nutrients, including: phosphorus $(\mathrm{P})$, calcium $(\mathrm{Ca})$, 
potassium (K), magnesium (Mg), sulphur (S) and nitrogen (N) (Mann 2002). Improvement of soil pH, electrical conductivity (EC), CEC and soil $\mathrm{C}$ were also reported (Chintala et al. 2014; Sohi et al. 2009).

\section{Biochar and soil physical properties}

Soil physical properties largely determine rooting depth and the availability of air and water within the rooting zone (Downie 2009). Bulk density $\left(\rho_{\mathrm{a}}\right)$ is one of the most important soil characteristics affecting rainfall infiltration (Ueckert et al. 1978). In a meta-analysis, Omondi et al. (2016) obtained an average value of $7.6 \%$ reduction in $\rho_{\mathrm{a}}$ following biochar application; this was attributed to the initial low $\rho_{\mathrm{a}}$ of biochar. Biochar impact on soil $\rho_{\mathrm{a}}$ varies, however, with application rate and soil type. Biochar amendment at $10 \mathrm{t} \mathrm{ha}^{-1}$ significantly reduced soil $\rho_{\mathrm{a}}$ in an Alfisol low in organic carbon, but had no effect in an Andosol high in organic carbon (Herath et al. 2013). Ventura et al. (2013) revealed an inverse linear correlation between $\rho_{\mathrm{a}}$ and biochar application rates $\left(30\right.$ and $60 \mathrm{t} \mathrm{ha}^{-1}$ ) for $5 \mathrm{~cm}$ and $10 \mathrm{~cm}$ depths, on a sub-alkaline clay loam soil.

Soil total porosity $(\Theta)$ affects rooting zone processes such as plant water uptake and soil microbial respiration by influencing gas movement (Hillel 2004). Increase in soil $\Theta$ after biochar application was found to be rate and soil specific: $4 \%, 3.5 \%, 8.6 \%$ and $19 \%$ increases were recorded, respectively, for low $\left(<20 \mathrm{tha}^{-1}\right)$, medium $\left(21-40 \mathrm{t} \mathrm{ha}^{-1}\right)$, high (41-80 $\left.\mathrm{t} \mathrm{ha}^{-1}\right)$ and very high $\left(>80 \mathrm{tha}^{-1}\right)$ application rates (Omondi et al. 2016). The same author also noted an increase of $7.5 \%$ in $\Theta$ in coarse-textured soils (sandy loam and coarser) and $7.1 \%$ in fine-textured soils (clay loam and finer). However, Hardie et al. (2013) found no influence of biochar on $\Theta$ by either direct pore contribution, creation of accommodation pores or improved aggregate stability, 30 months after application at $47 \mathrm{tha}^{-1}$ of green waste biochar produced at $550{ }^{\circ} \mathrm{C}$ on a sandy loam soil.

Compared to other studies on soil physical parameters, there is limited comparable information on biochar impact on soil saturated hydraulic conductivity (Ks) (Castellini et al. 2015). Soil Ks governs water infiltration and solute movement within the soil profile, thus influencing the likelihood of soil surface runoff after a heavy rainfall or irrigation event (Omondi et al. 2016). Biochar produced using mesquite wood (Prosopis sp.) at $400{ }^{\circ} \mathrm{C}$ (average rate of $133 \mathrm{t} \mathrm{ha}^{-1}$ ) decreased by $92 \%$ and by $67 \%$ the Ks of very permeable organic soil, but increased that of less permeable soils by $328 \%$ (Barnes et al. 2014; Githinji 2014). Laird et al. (2010a, b) observed no change in Ks of soil with intermediate permeability (repacked fine-loamy soil), 500 days after incorporating biochar made from slow pyrolysis of hardwood (Quercus and Carya spp.) applied at rates of 0, 5, 10 and $20 \mathrm{~g}$ biochar $\mathrm{kg}^{-1}$ soil.
Available water content (AWC) of soil is a key property in tropical climates because it contributes to reduce plant water stress. If biochar is able to increase soil water reserves in agricultural soils, it may be possible to reduce irrigation frequency and volume. Biochar was reported to mainly improve the AWC of poorly structured soils. Glaser et al. (2002) noted an increase of $18 \%$ in AWC on Terra Preta soils. Devereux et al. (2012) corroborated this result, reporting improved water retention through a change in soil porosity, pore size, bulk density and wetting ability, on repacked sandy loam soil amended with biochar made from wood charcoal. Ouyang et al. (2013) obtained an increased in the AWC of $5.2 \%$ for silty clay soil and $10.6 \%$ for sandy loam soil, using a biochar made from dairy manure at a ratio of $2 \% 5 \mathrm{cmw} / \mathrm{w}$ in dry weight basis. However, Ventura et al. (2013) found no difference in soil water retention on a clay loam, 2 years after application of biochar made from fruit tree pruning residues using a traditional oven, at rates of 10 , 30 and $60 \mathrm{t} \mathrm{ha}^{-1}$. Similarly, Ojeda et al. (2015) in a greenhouse experiment indicated no influence of biochar on water retention of a sandy loam after 1 and 20 months, using six types of biochar produced from different biomass sources (pine, poplar or sludge) and pyrolysis processes (slow, fast or gasification), applied at a mean dose of $0.018 \mathrm{~kg}$ biochar $\mathrm{kg}^{-1}$ soil.

\section{Biochar and soil chemical properties}

Soil $\mathrm{pH}$ is one of the fundamental soil properties influencing nutrient availability and many soil chemical processes (HadiAkbar Basri et al. 2013). Sanchez et al. (1983) observed that biochar increased the $\mathrm{pH}$ of amended soils by $0.4-1.2 \mathrm{pH}$ units, with greater increases in sandy and loamy soils than in clayey soils. The short- and long-term implications of biochar on $\mathrm{N}$ immobilization and mineralization are specific to soil-biochar interactions (Clough et al. 2013; Prommer et al. 2014). In some cases, biochar application could decrease soil $\mathrm{N}$ availability and plant tissue $\mathrm{N}$ concentration (Barbosa de Sousa et al. 2014; Bargmann et al. 2014). In other cases, $\mathrm{N}$ and $\mathrm{P}$ uptake in corn plants grown in a sandy loam was increased after application of wood biochar but decreased in a silt loam soil (Yeboah et al. 2009). This is explained by the possible sorption of $\mathrm{N}$ by biochar (Reverchon et al. 2014) or immobilization of mineral $\mathrm{N}$ due to increased soil $\mathrm{C} / \mathrm{N}$ ratio and input of labile $\mathrm{C}$ (Ippolito et al. 2014). Mitigation of $\mathrm{N}$ leaching loss following biochar addition reported by Zheng et al. (2013) was in part attributed to an increase in soil water holding capacity (WHC).

Reported mechanisms by which biochar can affect soil $\mathrm{P}$ content and plant uptake of $\mathrm{P}$ include: changing soil environment for microorganisms (Atkinson et al. 2010); alteration of soil $\mathrm{P}$ availability through anion exchange capacity (DeLuca et al. 2009); reduced P leaching due to sorption of 
both orthophosphate and organic $\mathrm{P}$ by biochar (Laird et al. 2010a, b); and direct release of soluble $\mathrm{P}$ after application (Parvage et al. 2013). However, we noted inconsistent results as to whether biochar application enhances $P$ sorption or its release. Enhanced phosphorus availability in biochar was reported to be greatly affected by pyrolysis temperature regardless of feedstock; lower pyrolysis temperature biochar contained more potentially available $\mathrm{P}$ (Xu et al. 2016a, b). Soil $\mathrm{P}$ availability is also influenced by interaction with the soil conditions and properties, e.g. retention time in soil, coexistence of other anions and nutrients on exchange sites and soil acidity. The incorporation of biochars to acidic soil at $40 \mathrm{~g} \mathrm{~kg}^{-1}$ (4\%) reduced the sorption and increased available P. In calcareous soil, application of alkaline biochars (corn stover and switchgrass biochars) significantly increased the sorption of $\mathrm{P}$ and decreased its availability (Chintala et al. 2014). Phosphorus release by biochars was also found to be highly dependent on the presence of other cations $\left(\mathrm{Ca}^{2+}, \mathrm{Mg}^{2+,} \mathrm{Al}^{3+}, \mathrm{Fe}^{2+}\right)$ in the soil solution. Slow release was found to be due to the formation of precipitates between dissolved $\mathrm{P}$ and excessive $\mathrm{Ca}^{2+}$ and $\mathrm{Mg}^{2+}$ in an alkaline milieu (Qian et al. 2013), while Fe-P and Al-P bonds were observed in more acidic soils (Xu et al. 2014).

Biochar seems to be one of the most effective materials reducing soil $\mathrm{K}$ losses in regions with high rainfall (Widowati and Asnah 2014). Several studies reported soil exchangeable $\mathrm{K}$ increase after biochar application. This impact was in part due to a direct supply of $\mathrm{K}$ from biochar (Zong et al. 2016) or by indirect improvement in fertilizer use efficiency by adsorption of nutrients on exchange surfaces thus reducing leaching loss (Widowati and Asnah 2014).

From the cited literature, it is evident that the influence of biochar on soil physico-chemical properties is highly variable. Biochar effects on soil properties depend on factors including biochar properties (influenced by feedstock type, pyrolytic conditions), application rate, soil type, time after application and the interactions among these factors. Biochar appears to have more influence in coarse-textured soils, poorly drained or excessively drained soils, poorly structured soils and soils with low organic carbon content. Less influence is noted on soils containing high organic matter, in finetextured and well-structured soils (Biederman and Stanley Harpole 2013; Burrell et al. 2016; Omondi et al. 2016).

Few studies have evaluated the effect of tillage in interaction with biochar application, such as in the context of the common cultural system of furrows and ridges (FR) in Cameroon (versus flat ploughing, FP). Considering the former system is predominant in many underdeveloped countries (because of topography, small size of most farms in forested zones or the low mechanization level) and has been proven appropriate on humid soils (Ker 1995), we investigated the effect of biochar in this context. We discuss how the addition of biochar affects physical and chemical properties of an oxisol cultivated under two different tillage modes for corn production in Cameroon. Straw is also considered in our study since it is an agricultural residue generally buried in conjunction with the FR tillage mode, and which is proposed as a raw material for biochar production.

\section{Materials and methods}

\section{Site description and irrigation system}

The study was conducted on an experimental field in the western highlands of Cameroon in Central Africa $\left(5^{\circ} 36^{\prime} 52^{\prime \prime} \mathrm{N}, 10^{\circ} 16^{\prime} 85^{\prime \prime} \mathrm{E}\right)$ at $1418 \mathrm{~m}$ of altitude. The site is characterized by a typical weathered red soil with $5 \%$ slope, which had been under fallow for 3 years. The climate is tropical wet with a mean annual rainfall of $1850 \mathrm{~mm}$ mainly from March to October. Mean maximum and minimum temperatures are $29.4{ }^{\circ} \mathrm{C}$ and $12.9^{\circ} \mathrm{C}$. The soil has $34 \%$ clay, $26 \%$ silt and $40 \%$ sand thus representing a clay loam texture (USDA 2014), with an acid pH of 5.8 and a relatively low bulk density. Detailed soil characteristics are presented in Tables 1 and 2.

To ensure adequate soil moisture, an irrigation system was designed based on the following parameters: basic infiltration rate of the soil estimated at $2.50 \times 10^{-4} \mathrm{~m} \mathrm{~s}^{-1}$ using the double ring infiltrometer method (ASTM-D5093 2008), corn water requirements as per growing stages (FAO 2016), actual evapotranspiration and soil water retention capacity. Water from a nearby river was pumped to irrigate the experimental plots by sprinklers, twice weekly during the dry season (first production period, from January to May 2014) and then occasionally, according to rain events during the rainy season (second production period, from July to November, 2014).

\section{Biochar production and characterization}

Biochars used in this study were made from local organic residues, eucalyptus tree bark (EB) and corncob (CCB). They were manufactured using a locally made retort kiln at a temperature of around $300{ }^{\circ} \mathrm{C}$. Physical, chemical and biological parameters of both $\mathrm{CCB}$ and $\mathrm{EB}$ were characterized (Djousse et al. 2017a) using methods described in Table 3 and their characteristics presented in Tables 1 and 2.

\section{Experimental setup}

The treatments were organized in a split-plot design, with the main plots being the soil tillage mode (FP vs FR system), and with the subplots being one of the four treatments (T2-T5) plus a control (T1). The subplots were $4 \times 4 \mathrm{~m}$, 
Table 1 Biochar and soil physical parameters

\begin{tabular}{|c|c|c|c|c|c|c|c|c|c|}
\hline \multirow[t]{2}{*}{ Symbols } & \multirow[t]{2}{*}{ Parameters } & \multirow[t]{2}{*}{ Units } & \multirow[t]{2}{*}{$\mathrm{CCB}^{\mathrm{a}}$} & \multirow[t]{2}{*}{$\mathrm{EB}^{\mathrm{a}}$} & \multirow{2}{*}{$\begin{array}{l}\text { Value at } \\
\text { beginning } \\
( \pm C V)\end{array}$} & \multicolumn{2}{|c|}{$\begin{array}{l}\text { Value at the end of } \\
\text { first } P P( \pm C V)\end{array}$} & \multicolumn{2}{|c|}{$\begin{array}{l}\text { Value at the end of second } \\
\operatorname{PP}( \pm C V)\end{array}$} \\
\hline & & & & & & FR & FP & $\overline{\mathrm{FR}}$ & FP \\
\hline \multicolumn{10}{|c|}{ Granular size parameters } \\
\hline- & $0.05<\%<2$ & $\%$ & 97 & 89 & 40 & $42 \pm 1$ & $41 \pm 1$ & $42 \pm 0$ & $42 \pm 0$ \\
\hline- & $0.025<\%<0.05$ & $\%$ & 3 & 10 & 26 & $24 \pm 2$ & $25 \pm 2$ & $26 \pm 0$ & $26 \pm 0$ \\
\hline- & $\%<0.025$ & $\%$ & 0 & 1 & 34 & $34 \pm 1$ & $34 \pm 0$ & $32 \pm 0$ & $32 \pm 0$ \\
\hline- & Texture & - & & - & & Clay loa & & & \\
\hline MPD & Mean particle diameter & $\mathrm{mm}$ & 0.24 & 0.13 & - & - & - & - & - \\
\hline $\mathrm{UC}$ & Uniformity coefficient & - & 2.12 & 2.43 & - & - & - & - & - \\
\hline \multicolumn{10}{|c|}{ Porosity related parameters } \\
\hline$\rho_{\mathrm{a}}$ & Bulk density & $\mathrm{g} \mathrm{cm}^{-3}$ & 0.33 & 0.46 & $0.76 \pm 10$ & $0.75 \pm 9$ & $0.72 \pm 13$ & $0.80 \pm 9$ & $0.77 \pm 9$ \\
\hline$\rho_{\mathrm{s}}$ & Particle density ${ }^{\mathrm{b}}$ & $\mathrm{g} \mathrm{cm}^{-3}$ & 1.62 & 1.63 & 2.65 & 2.65 & 2.65 & 2.65 & 2.65 \\
\hline$\Theta$ & Total porosity & $\mathrm{m}^{3} \mathrm{~m}^{-3}$ & 0.79 & 0.72 & $71 \pm 4$ & $0.72 \pm 3$ & $0.73 \pm 5$ & $0.70 \pm 4$ & $0.71 \pm 4$ \\
\hline \multicolumn{10}{|c|}{ Water related parameters } \\
\hline Өs & Saturation water & $\mathrm{m}^{3} \mathrm{~m}^{-3}$ & - & - & $0.68 \pm 4$ & $0.62 \pm 1$ & $0.74 \pm 19$ & $0.62 \pm 16$ & $0.72 \pm 9$ \\
\hline Өr & Residual water & $\mathrm{m}^{3} \mathrm{~m}^{-3}$ & - & - & $0.27 \pm 11$ & $0.21 \pm 4$ & $0.36 \pm 32$ & $0.18 \pm 48$ & $0.34 \pm 24$ \\
\hline AWC & Available water content & $\mathrm{m}^{3} \mathrm{~m}^{-3}$ & - & - & $0.04 \pm 16$ & $0.06 \pm 3$ & $0.08 \pm 21$ & $0.14 \pm 29$ & $0.15 \pm 23$ \\
\hline $\mathrm{Ks}$ & Saturated hydraulic conductivity & $\mathrm{m} \mathrm{s}^{-1}$ & - & - & $2.1 \mathrm{E}-4 \pm 9$ & - & - & $2.4 \mathrm{E}-4 \pm 58$ & $4.1 \mathrm{E}-4 \pm 70$ \\
\hline- & Capillary rise & $\mathrm{g} \mathrm{g} \mathrm{h}^{-1}$ & 5.07 & 5.19 & - & - & - & - & - \\
\hline$\Theta x$ & Relative humidity sorption & $\mathrm{g} \mathrm{g} \mathrm{h}^{-1}$ & 6.17 & 6.14 & - & - & - & - & - \\
\hline
\end{tabular}

NB: $C C B$ Corncob biochar, $E B$ Eucalyptus biochar, $P P$ production period, $F P$ flat plot, $F R$ furrow-ridges

${ }^{a}$ Adapted from Djousse et al. (2017a)

${ }^{\mathrm{b}}$ Soil particle density assumed to be 2.65 (not measured as with biochar)

Table 2 Biochar and soil chemical parameters

\begin{tabular}{|c|c|c|c|c|c|c|c|c|c|}
\hline \multirow[t]{2}{*}{ Symbols } & \multirow[t]{2}{*}{ Parameters } & \multirow[t]{2}{*}{ Units } & \multirow[t]{2}{*}{$\mathrm{CCB}^{\mathrm{a}}$} & \multirow[t]{2}{*}{$\mathrm{EB}^{\mathrm{a}}$} & \multirow[t]{2}{*}{ Value at beginning } & \multicolumn{2}{|c|}{$\begin{array}{l}\text { Value at the end of } \\
\text { first PP }\end{array}$} & \multicolumn{2}{|c|}{$\begin{array}{l}\text { Value at the end of } \\
\text { second PP }\end{array}$} \\
\hline & & & & & & Treated & Control & Treated & Control \\
\hline $\mathrm{pH}_{\mathrm{H} 20}$ & $\mathrm{pH}$ water & - & 9.31 & 8.11 & $4.4 \pm 0.03$ & $5.4 \pm 0.1$ & $5.1 \pm 0.0$ & $5.4 \pm 0.1$ & $4.9 \pm 0.0$ \\
\hline $\mathrm{EC}$ & Electrical conductivity & $\mathrm{S} \mathrm{m}^{-1}$ & 0.028 & 0.068 & $0.05 \pm 0.1$ & $0.04 \pm 0.2$ & $0.04 \pm 0.2$ & $0.11 \pm 0.2$ & $0.10 \pm 0.2$ \\
\hline (CEC) & Sum of cations & $\operatorname{cmol}(+) \mathrm{kg}^{-1}$ & 28.55 & 24.24 & $12.7 \pm 0.1$ & $12.8 \pm 0.3$ & $12.5 \pm 0.3$ & $11.2 \pm 0.3$ & $10.8 \pm 0.3$ \\
\hline $\mathrm{N}$ & Total Nitrogen & $\mathrm{g} \mathrm{g}^{-1} \times 100$ & 0.88 & 0.47 & $0.1 \pm 0.1$ & $0.1 \pm 0.1$ & $0.1 \pm 0.1$ & $0.1 \pm 0.2$ & $0.1 \pm 0.2$ \\
\hline $\mathrm{P}$ & Exchangeable Phosphorus & $\operatorname{cmol}(+) \mathrm{kg}^{-1}$ & 4.56 & 4.25 & $8.7 \pm 0.1$ & $7.79 \pm 0.4$ & $7.2 \pm 0.5$ & $4.89 \pm 0.3$ & $4.2 \pm 0.4$ \\
\hline $\mathrm{K}$ & Exchangeable Potassium & $\operatorname{cmol}(+) \mathrm{kg}^{-1}$ & 26.47 & 7.54 & $0.07 \pm 0.1$ & $9.0 \pm 0.8$ & $5.7 \pm 0.4$ & $1.1 \pm 0.4$ & $0.9 \pm 0.4$ \\
\hline $\mathrm{Ca}$ & Exchangeable Calcium & $\operatorname{cmol}(+) \mathrm{kg}^{-1}$ & 0.80 & 14.73 & - & - & - & - & - \\
\hline $\mathrm{Mg}$ & Exchangeable Magnesium & $\operatorname{cmol}(+) \mathrm{kg}^{-1}$ & 0.78 & 1.01 & - & - & - & - & - \\
\hline $\mathrm{Na}$ & Exchangeable Sodium & $\operatorname{cmol}(+) \mathrm{kg}^{-1}$ & 0.50 & 0.96 & $0.01 \pm 0.0$ & $1.5 \pm 0.4$ & $1.3 \pm 0.2$ & $0.8 \pm 0.2$ & $0.8 \pm 0.0$ \\
\hline $\mathrm{OM}$ & Organic matter & $\mathrm{g} \mathrm{g}^{-1} \times 100$ & - & - & $3.8 \pm 0.1$ & $8.8 \pm 0.3$ & $6.6 \pm 0.3$ & $10.3 \pm 0.2$ & $8.4 \pm 0.4$ \\
\hline- & Graphitic Carbon & $\mathrm{g} \mathrm{g}^{-1} \times 100$ & 37.7 & 24.9 & - & - & - & - & - \\
\hline $\mathrm{OC}$ & Organic carbon & $\mathrm{g} \mathrm{g}^{-1} \times 100$ & 29.7 & 27.8 & $2.2 \pm 0.1$ & $5.1 \pm 0.3$ & $3.8 \pm 0.3$ & $5.9 \pm 0.2$ & $4.9 \pm 0.4$ \\
\hline $\mathrm{C} / \mathrm{N}$ & Carbon nitrogen ratio & - & 76 & 112 & $30 \pm 0.0$ & $82.5 \pm 0.3$ & $62.7 \pm 0.3$ & $85.5 \pm 0.3$ & $78.4 \pm 0.5$ \\
\hline
\end{tabular}

NB: Soil samples collected from the top $10 \mathrm{~cm}$ of soil; $C C B$ Corncob biochar; $E B$ Eucalyptus biochar, $F R$ furrow-ridges plots, $F P$ flat plots, $P P$ production period

${ }^{a}$ Adapted from Djousse et al. (2017a)

separated from each other by an alley of $0.8 \mathrm{~m}$. Replicates were assured with three blocks set perpendicularly to the slope gradient. The control consisted of fertilizer and the incorporation of straw (T1), while the other treatments 


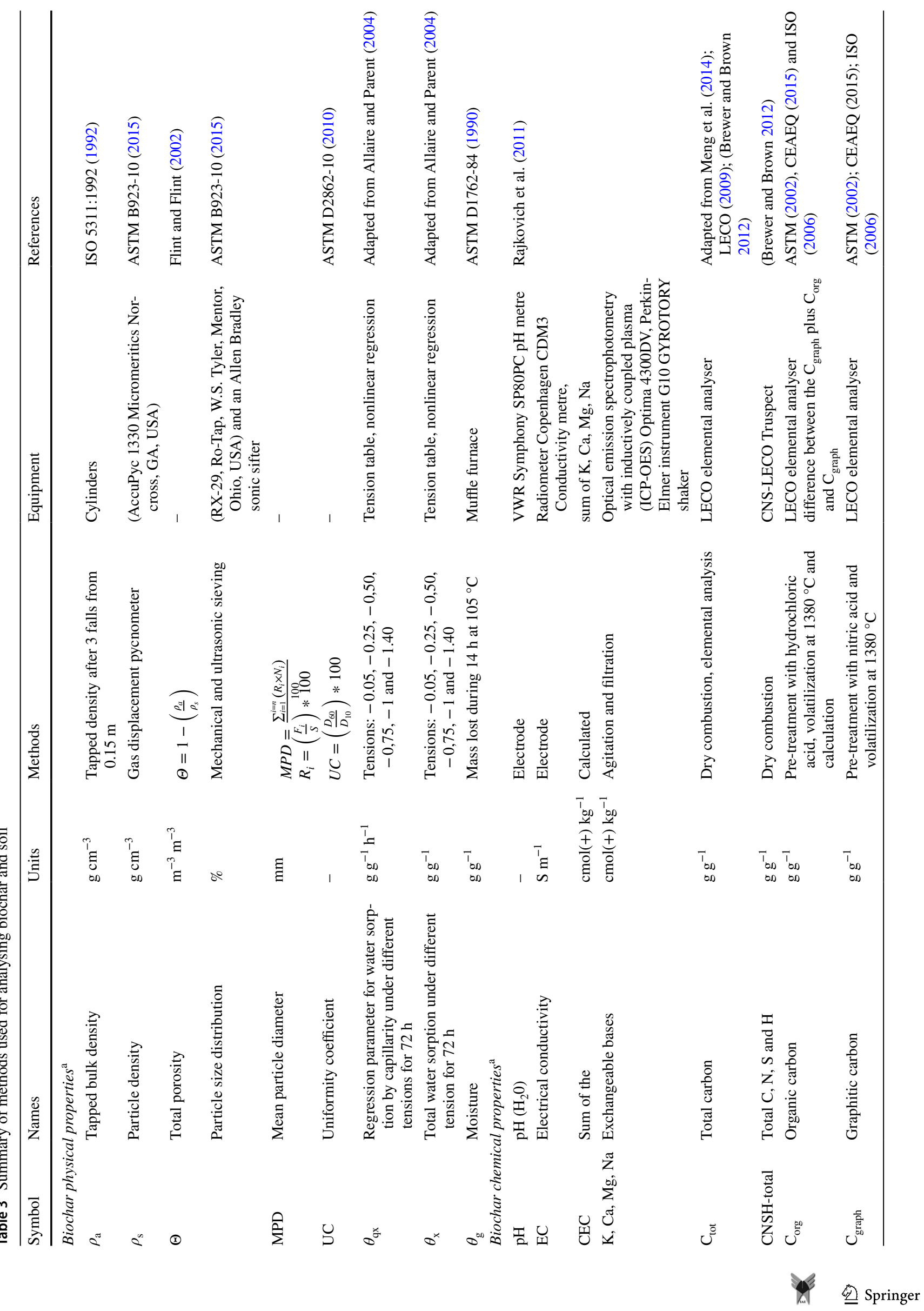




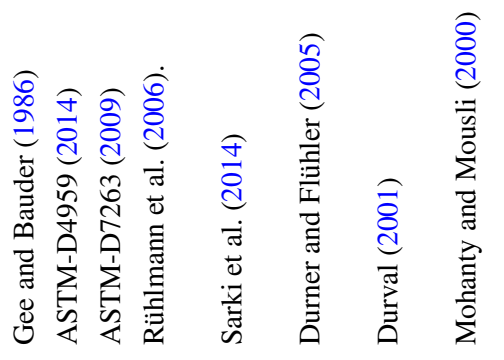

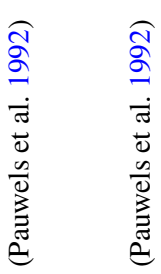

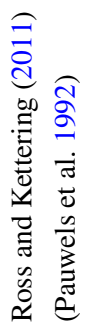

อี
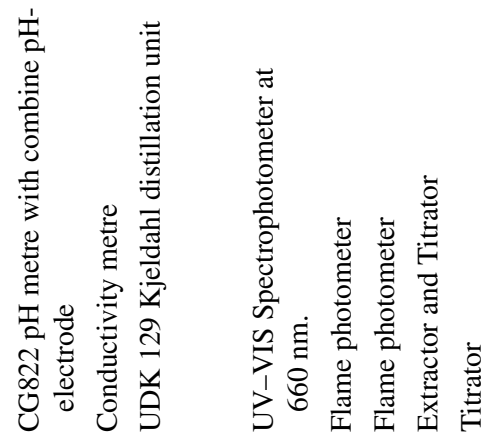

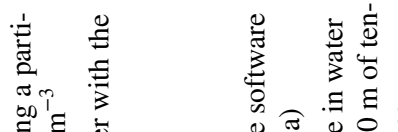

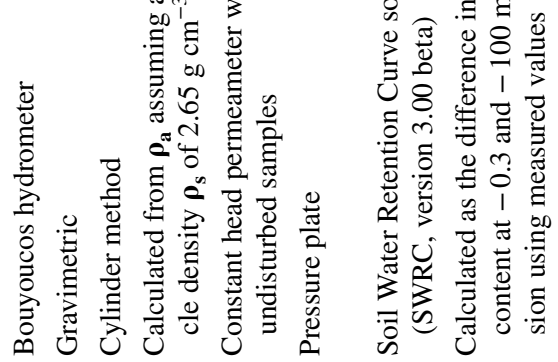

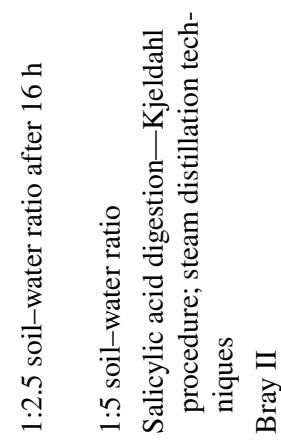

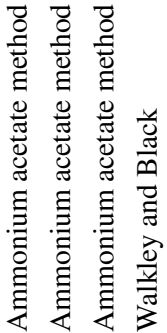

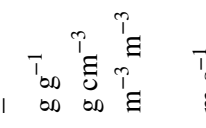

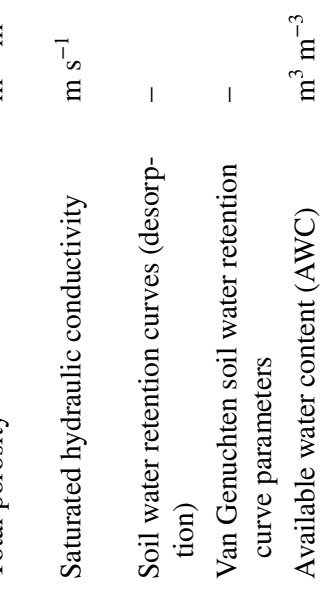

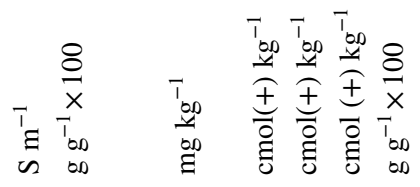

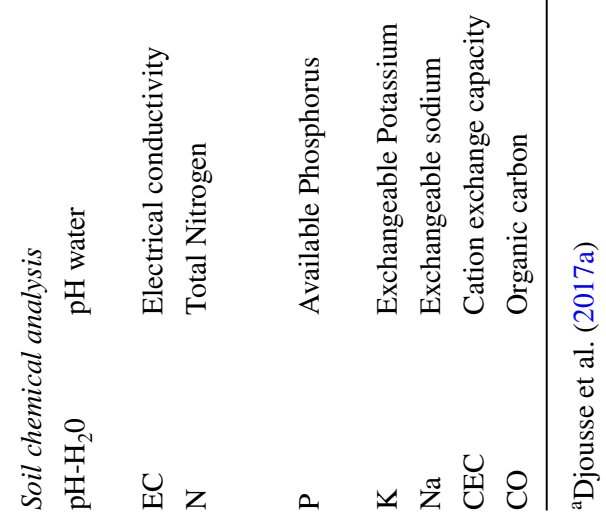


consisted of fertilizer with the addition of CCB (T2); fertilizer with the addition of $\mathrm{EB}$ (T3); fertilizer and the addition of CCB and straw (T4); and fertilizer with the addition of EB and straw (T5). Fertilization consisted of manual application of 4 (20-10-10) at the rate of $200 \mathrm{~kg} \mathrm{ha}^{-1}$ and urea (46-0-0) at the rate of $100 \mathrm{~kg} \mathrm{ha}^{-1}$; this is the standard application rate used by farmers in the locality. The land was tilled using a rotor cultivator for FP and a hoe for FR. Due to its hilly landscape and the small size of agricultural plots, farmers in the region principally use this latter method. Straw from grasses present in each plot was either buried (T4 and T5) or removed (T2 and T3). For FR, grasses were pulled out with a hoe, then either kept aside, or partially buried in the furrow by applying a layer of soil over top. Two weeks later, biochar and fertilizer were applied manually on the entire surface of ridges, then immediately covered at a depth between 10 and $15 \mathrm{~cm}$ with a second layer of soil, in order to prepare the seedbed. Each plot had three ridges of $1 \mathrm{~m}$ each, spaced $50 \mathrm{~cm}$ apart. For FP, we first ploughed using the rotor cultivator at $10-15 \mathrm{~cm}$ depth. Two weeks later, biochar and fertilizer were manually spread on the entire surface of the plot and a second plough immediately completed to bury biochar and fertilizer, and to prepare the seedbed for sowing. Improved corn seeds (PANNAR 12TM) were sown manually at about $4 \mathrm{~cm}$ depth, Tables 1 and 4 at a density of 4 plants $\mathrm{m}-2(50 \times 60 \mathrm{~cm}$ in ridges and $50 \times 65 \mathrm{~cm}$ in FP). The plots were irrigated when necessary as described in Sect. 2.1.

After harvesting (5 months later), the agricultural residues were removed from the field and plots were ploughed using the hoe for ridges and the rotor cultivator for FP surfaces. Ridges were not moved to form new ones, but were instead disturbed and remained in the same position. A second corn production period of 5 months was then completed on the same plots, without application of either fertilizer or biochar, as generally done by farmers in the locality.

\section{Soil sampling and analysis}

Soil samples were collected three times during the experiment: before ploughing, at the end of the first corn production before the second ploughing (6 months after treatment application), and at the end of the second production period (6 months after the second ploughing). For chemical and textural analysis, soil samples were collected between 1 and
Table 4 Analysis of variance for soil physical parameters (degree of freedom and $p$ values)

\begin{tabular}{|c|c|c|c|c|c|c|c|c|c|}
\hline \multirow[t]{2}{*}{ Parameters } & \multirow[t]{2}{*}{$\mathrm{DF}$} & \multirow[t]{2}{*}{$\Theta$} & \multirow[t]{2}{*}{$\theta_{\mathrm{r}}$} & \multirow[t]{2}{*}{$\theta_{\mathrm{s}}$} & \multirow[t]{2}{*}{$\rho_{\mathrm{a}}$} & \multirow[t]{2}{*}{ AWC } & \multirow[t]{2}{*}{ Ks } & \multicolumn{2}{|l|}{$\theta_{\mathrm{g}}$} \\
\hline & & & & & & & & $\mathrm{DF}$ & $p$ \\
\hline \multicolumn{10}{|l|}{ Treatment versus control } \\
\hline Production period (PP) & 1 & 0.003 & 0.22 & 0.15 & 0.007 & $<0.0001$ & - & 2 & $<0.00$ \\
\hline Treatment $(\mathrm{T})$ & 4 & 0.19 & 0.53 & 0.28 & 0.27 & 0.22 & 0.83 & 4 & 0.70 \\
\hline $\mathrm{T} \times \mathrm{PP}$ & 4 & 0.81 & 0.60 & 0.74 & 0.85 & 0.79 & - & 8 & 0.47 \\
\hline Soil tillage mode (STM) & 1 & 0.46 & 0.005 & 0.0009 & $<0.0001$ & 0.0072 & 0.19 & 1 & 0.045 \\
\hline $\mathrm{STM} \times \mathrm{PP}$ & 1 & 0.96 & 0.96 & 0.55 & 0.72 & $<0.0001$ & - & 2 & 0.34 \\
\hline $\mathrm{T} \times \mathrm{STM}$ & 4 & 0.99 & 0.65 & 0.19 & 0.65 & 0.005 & 0.33 & 4 & 0.60 \\
\hline $\mathrm{T} \times \mathrm{STM} \times \mathrm{PP}$ & 4 & 0.009 & 0.05 & 0.56 & 0.60 & 0.13 & - & 8 & 0.52 \\
\hline \multicolumn{10}{|l|}{ In between treatments } \\
\hline Biochar type (BT) & 1 & 0.75 & 0.64 & 0.46 & 0.78 & 0.76 & 0.56 & 1 & 0.43 \\
\hline $\mathrm{PP}$ & 1 & 0.007 & 0.39 & 0.09 & 0.01 & $<0.0001$ & - & 2 & $<0.0001$ \\
\hline $\mathrm{BT} \times \mathrm{PP}$ & 1 & 0.82 & 0.77 & 0.89 & 0.84 & 0.37 & - & 2 & 0.46 \\
\hline STM & 1 & 0.35 & 0.0005 & 0.0006 & 0.0002 & 0.08 & 0.34 & 1 & 0.17 \\
\hline $\mathrm{BT} \times \mathrm{STM}$ & 1 & 0.69 & 0.87 & 0.62 & 0.7 & 0.90 & 0.63 & 1 & 0.17 \\
\hline $\mathrm{STM} \times \mathrm{PP}$ & 1 & 0.71 & 0.99 & 0.80 & 0.87 & 0.0002 & - & 2 & 0.49 \\
\hline $\mathrm{BT} \times \mathrm{STM} \times \mathrm{PP}$ & 1 & 0.18 & 0.15 & 0.34 & 0.26 & 0.44 & - & 2 & 0.72 \\
\hline Straw (S) & 1 & 0.25 & 0.49 & 0.47 & 0.31 & 0.03 & 0.74 & 1 & 0.62 \\
\hline $\mathrm{BT} \times \mathrm{S}$ & 1 & 0.45 & 0.23 & 0.11 & 0.50 & 0.78 & 0.85 & 1 & 0.73 \\
\hline $\mathrm{S} \times \mathrm{PP}$ & 1 & 0.21 & 0.40 & 0.66 & 0.26 & 0.77 & - & 2 & 0.38 \\
\hline $\mathrm{BT} \times \mathrm{S} \times \mathrm{PP}$ & 1 & 0.86 & 0.95 & 0.08 & 0.87 & 0.73 & - & 2 & 0.84 \\
\hline $\mathrm{S} \times \mathrm{STM}$ & 1 & 0.82 & 0.51 & 0.25 & 0.81 & 0.0005 & 0.80 & 1 & 0.44 \\
\hline $\mathrm{BT} \times \mathrm{S} \times \mathrm{STM}$ & 1 & 0.76 & 0.95 & 0.82 & 0.29 & 0.50 & - & 1 & 0.35 \\
\hline $\mathrm{S} \times \mathrm{STM} \times \mathrm{PP}$ & 1 & 0.0005 & 0.01 & 0.04 & 0.2865 & 0.12 & - & 2 & 0.12 \\
\hline
\end{tabular}

NB: $D F$ degree of freedom; $\Theta$ total porosity; $\theta_{r}$ residual water $\theta_{\mathrm{s}}$ water content at saturation, $\rho_{a}$ bulk density, $A W C$ available water content, $K s$ saturated hydraulic conductivity, $\theta_{g}$ gravimetric water content Significant $p$ values are in bold characters 
$10 \mathrm{~cm}$ depth, while a $100 \mathrm{~cm}^{3}$ core was sampled for other physical analyses. For initial soil characterization, 12 undisturbed soil cores ( 4 per block) and 3 composite soil samples (12 sub-samples per block) were collected. At the end of the first production period, 30 soil cores ( 1 per plot) and 30 composite samples (4 random sub-samples per plot) were also collected following diagonal transects. A similar soil sampling was carried out at the end of the second production period. During this period, 30 composite soil samples were also collected at 2-week intervals to assess gravimetric soil moisture content. These composite samples were immediately placed in plastic bags after collection to avoid evaporation. Theses samples were analysed as described in Table 3.

\section{Statistical analysis}

The data were analysed using the GLIMIX procedure of SAS followed by the Tukey HSD test for multiple comparisons. Analysis was carried out in two phases. First, the treatments $\mathrm{T} 2, \mathrm{~T} 3, \mathrm{~T} 4$ and $\mathrm{T} 5$ were compared to the control (T1) for the response variables. Second, the treatments were compared to each other, in order to interpret the effects of biochar type, soil tillage mode, production period and presence or absence of straw.

\section{Results and discussion}

\section{Biochar and soil physical properties}

\section{Bulk density and total porosity}

There was no significant effect of biochar treatment $(p=0.27)$ or biochar type $(p=0.78)$ on $\rho_{\mathrm{a}}, 6$ and 12 months after its application (Tables 1, 4).

The $\rho_{\mathrm{a}}$ of our biochar ranged from 0.33 to $0.46 \mathrm{~g} \mathrm{~cm}^{-3}$, while that of our soil was $0.76 \mathrm{~g} \mathrm{~cm}^{-3}$. This was quite low compared to $\rho_{\mathrm{a}}$ of mineral soils $\left(1-2 \mathrm{~g} \mathrm{~cm}^{-3}\right)$ but closer to $\rho_{\mathrm{a}}$ of organic soils $\left(<1 \mathrm{~g} \mathrm{~cm}^{-3}\right)$ (Hossain et al. 2015), probably because our plot was an old farmland and sampling was done only in the $h$ dark surface layer. The effect of biochar was thus expected to be lower considering the bulk density of our soil (Verheijen et al. 2010). Similarly, Rogovska et al. (2016) did not find effects on $\rho_{\mathrm{a}} 3$ years after application of biochar made at $450{ }^{\circ} \mathrm{C}$ from mixed hardwood biochar (Quercus spp., Ulmus spp. and Carya spp.) applied at the rate of 9.8 and $18.4 \mathrm{t} \mathrm{ha}^{-1}$. Our results are in apparent disagreement with the work reported by Karhu et al. (2011) on agricultural soil, by Ventura et al. (2013) on a clay loam soil and a meta-analysis done by Omondi et al. (2016) on biochar-amended soils. This could be explained by the initial soil properties in our study. Flat plots (FP) had lower $\rho_{\text {a }}$ compared to FR and $\rho_{\mathrm{a}}$ also decreased during the second production period; all these are due to soil mixing from one production period to another. All reported positive effects of biochar on $\rho_{\mathrm{a}}$, over a wide range of biochar application rates, are explained by the low $\rho_{\mathrm{a}}$ of biochar resulting in lower soil $\rho_{\mathrm{a}}$ after application. The $\Theta$ was not affected by treatment or biochar type. These findings could be explained in part by either the initial high porosity of biochar, leading to an increase in total soil micro-pores, or an alteration in soil pore size distribution. In the present case, there was no difference between the initial porosity of our biochars (79\% for CCB and $72 \%$ for EB) and that of the soil (71\%) (Tables 1,4), thus explaining our observations. Once more, these results are dissimilar to many previous studies (Bhattarai et al. 2015; Omondi et al. 2016), all of which reported increased soil porosity after the addition of biochar from different sources. Indeed, our results are supported by Omondi et al. (2016). The authors meta-analysis reported that soil porosity was not significantly affected by addition of biochar in highly porous soils and at low and medium application rates $\left(3.5-4 \%\right.$ which is equivalent to $23-36 \mathrm{~kg} \mathrm{ha}^{-1}$ based on our biochar bulk density and assuming incorporation at $20 \mathrm{~cm}$ depth). These rates were almost twice those used in the present experiment and suggest that the studied oxisol might need higher doses of biochar with higher porosity to effectively alter the $\Theta$. However, when incorporated into FP, straw increased the $\Theta$ during the second production period (Table 4). This could be due to increase in soil OM content following straw mineralization. Production period and soil tillage mode (STM) influenced $\rho_{\mathrm{a}}$ (Table 4), values being higher during the second production period compared to the first; and in FP compared to FR. The observed differences may be due to repeated tillage and to the effect of rainwater beating that favour soil aggregate breakdown and compaction. This is also in line with $\Theta$ that was lower during the second production period compared to the first $(p=0.003)$.

\section{Saturated hydraulic conductivity (Ks), available water content (AWC) and water retention curve parameters $\left(\theta_{s^{\prime}}, \theta_{\mathrm{r}}\right)$}

We observed no change in Ks values during the experiment (Tables 1, 4). Previous authors reported either a net shortterm reduction in Ks after application of biochar in sand and organic soils (Barnes et al. 2014; Githinji 2014), a net increase (Herath et al. 2013; Uzoma et al. 2011) or no effect (Castellini et al. 2015; Ouyang et al. 2013). A net increase was related to the high porosity of biochar, while a net reduction was attributed either to the initial hydrophobicity of biochar or to the creation of torturous interstitial space between sand and biochar grains. Our results could be explained by the low biochar application rate, since many experiments in which a change was observed were characterized by higher rates (Omondi et al. 2016). In addition, Herath et al. (2013) reported that generally poorly drained soils exhibited a 
significant change in their Ks with biochar addition; this oxisol is well drained with high Ks $\left(2.06 \times 10^{-4} \mathrm{~m} \mathrm{~s}^{-1}\right)$. The high variability of Ks values could also have contributed to hinder statistical differences between biochar-amended and non-amended plots.

Biochar application had no significant effect on AWC $(p=0.22)$, independently of the type of biochar $(p=0.76)$ but production period did $(p<0.0001)$. This could be explained by the fact that our biochar was produced at a relatively low temperature $\left(300{ }^{\circ} \mathrm{C}\right)$, thus had higher levels of hydrophobic compounds impeding uptake of water into pore space, especially during the first production period. Reduction over time of this hydrophobicity, in addition to the increase in soil organic matter content (Table 2), could explain the higher value of AWC obtained during the second production period compared to the first. Hardie et al. (2013) also reported no significant effects of a green waste biochar applied at a rate of $51.8 \mathrm{tha}^{-1}$ on water retention curve parameters of a clay loam soil. Major et al. (2011) found no significant effect on either the water holding capacity or the Ks of a clay soil following wood biochar addition at the rate of $20 \mathrm{tha}^{-1}$. At an application rate similar to the present study, Jeffery et al. (2015) indicated no improvement in soil hydrological function of a sandy soil after biochar application at $10 \mathrm{tha}^{-1}$. Hence, the use of biochar at the equivalent rate of $15 \mathrm{tha}^{-1}$ may have also contributed to the observed lack of effect on hydrological function. In fact, some of the studies in which positive effects of biochar on soil hydraulic properties were reported used biochar application rates that are not feasible for field scale operational applications, such as $50 \mathrm{t} \mathrm{ha}^{-1}$ (Jeffery et al. 2015), 40, $80 \mathrm{t} \mathrm{ha}^{-1}$ (Jones et al. 2010), $88 \mathrm{tha}^{-1}$ (Gaskin et al. 2007) and $195 \mathrm{t} \mathrm{ha}^{-1}$ (Yu et al. 2013). Similarly, many studies reporting positive effects of biochar were carried out in pot experiments or with repacked soils under controlled environments, which do not reflect the field situation of oxisols (Hardie et al. 2013). However, soil AWC increased when straw was directly incorporated in flat plots, this could be due to fast mineralization of grasses and thus ready availability of organic matter and thus increased soil water storage.

Soil water content (SWC) was not influenced by biochar type or its presence but varied from one sampling period to another (Tables 1,4). This can be explained by the low water sorption capacity of our biochar as previously discussed (Fig. 1) as well as the soil type (clay loam), which already has a good saturation water content related to its clay content. The greater SWC and AWC observed in FP compared to FR (Fig. 2) can be explained by the fact that in FR, furrows act like drains, reducing the soil moisture in ridges.

Fitted values of van Genuchten parameters $\left(\theta_{\mathrm{s}}, \theta_{\mathrm{r}}\right)$ are presented in Table 1. Straw incorporated into soil in flat plots increased $\theta_{\mathrm{s}}$ and $\theta_{\mathrm{r}}$ during the second production period; this shares the same explanations as for those of

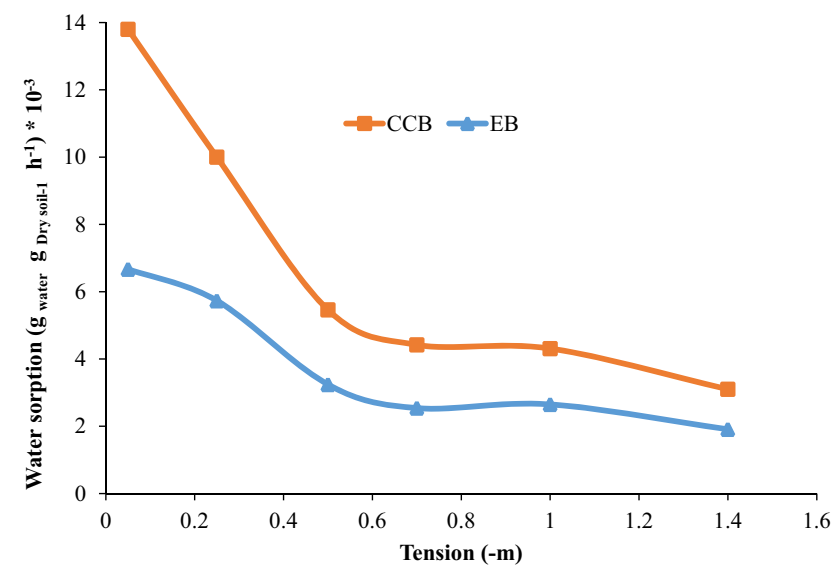

Fig. 1 Capillary rise of CCB and EB under tensions from $-0.05 \mathrm{~m}$ (very wet) to $-1.5 \mathrm{~m}$ (wet)

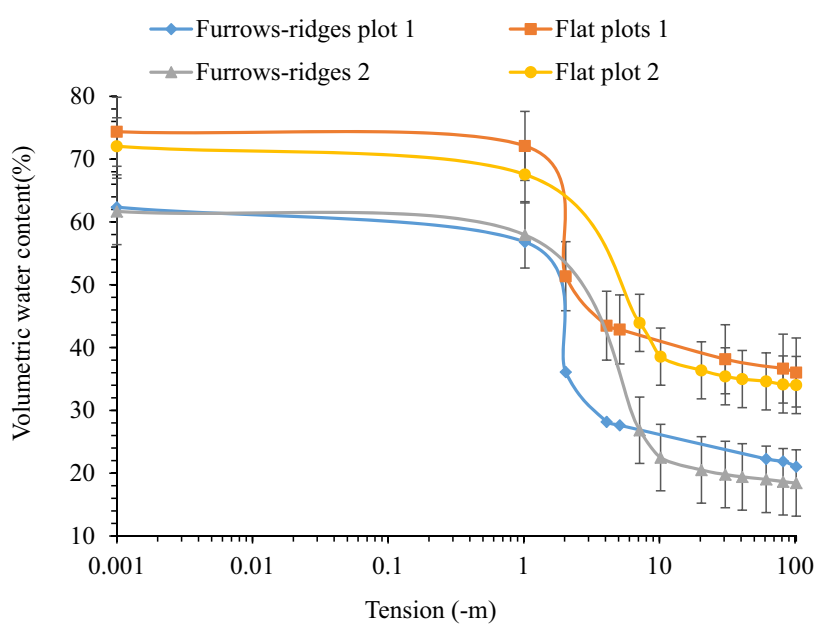

Fig. 2 Variation of soil water content as a function of production period and soil tillage mode

$\Theta$ and $\rho_{\mathrm{a}}$. The $\theta_{\mathrm{r}}$ was not affected by the addition of biochar $(p=0.53)$ nor by biochar type $(p=0.64)$. This was expected, as soil texture remains constant. Similar findings were reported by Uzoma (2011) with a biochar manufactured at $400{ }^{\circ} \mathrm{C}$ and applied at the rate of $10 \mathrm{t} \mathrm{ha}^{-1}$ on a sandy soil and by Eastman (2011) and Laird et al. (2010a, b) with an application rate of biochar up to $20 \mathrm{t} \mathrm{ha}^{-1}$ on a loam soil. Tillage mode, however, positively affected $\theta_{\mathrm{r}}$ $(p=0.005)$ with values being higher in FP during both production periods (Fig. 2). We hypothesize that organic matter content builds up more quickly in FP (grasses were sliced up with the rotor cultivator and buried) compared to FR (grasses were buried). In summary, biochar influenced none of the measured soil physical properties, but the interaction between straw, tillage mode and production periods did affect these properties. 


\section{Biochar and soil chemical characteristics}

Soil pH (Table 2) increased $(p=0.001) 6$ and 12 months after biochar application independently of the soil tillage mode; the average value was 5.10 in the control and 5.45 in treated plots during the first production period, and increased from 4.95 to 5.38 during the second production period; this could be due to the initial high $\mathrm{pH}$ value of these biochars. Pandian et al. (2016) reported similar results with an increase in $\mathrm{pH}$ between 0.5 and 0.6 units after application of biochar made of Prosopis on an acidic red soil at the rate of $5 \mathrm{t} \mathrm{ha}^{-1}$. Several studies found that biochar addition may alter $\mathrm{pH}$ levels and the availability of soil nutrients such as $\mathrm{Ca}$ or $\mathrm{Mg}$, while decreasing exchangeable $\mathrm{Al}^{3+}$ and $\mathrm{H}^{+}$ concentrations (Novak et al. 2009). Calcium and Mg were found to limit maize growth in highly weathered tropical soils (Major et al. 2010), or the availability of B and Mo, which are important cofactors in biological $\mathrm{N}$ fixation (Rondon et al. 2007).

The EC of soil was not affected by biochar application, probably due to the dilution effect of soil and because the soil already contains high levels of $\mathrm{Al}$ and $\mathrm{Fe}$, causing higher initial EC $\left(0.05 \pm 0.1 \mathrm{~S} \mathrm{~m}^{-1}\right)$ than the biochar $\left(0.028<\mathrm{EC}<0.068 \mathrm{~S} \mathrm{~m}^{-1}\right)$. However, the soil EC value significantly increased during the second production period in all plots. Also, straw positively interacted with soil when tilled flat, increasing EC. These are all imputable to the natural mineralization processes occurring in the soil since mineral fertilizers were not added during the second production. Soil CEC was not affected by any treatment, despite the higher value of biochar CEC $\left(24.24 \mathrm{cmol}(+) \mathrm{kg}^{-1}\right.$ for EB and $28.55 \mathrm{cmol}(+) \mathrm{kg}^{-1}$ for CCB) compared to that of the soil $\left(12.7 \mathrm{cmol}(+) \mathrm{kg}^{-1}\right)$. This could be due to a dilution effect and leaching, since measurements were taken 6 months after biochar application. Minimal or no changes in CEC were also observed after addition of pecan shellbased biochar at the rate of $40 \mathrm{tha}^{-1}$ to a fine-loamy soil (Novak et al. 2009).
Based on chemical analysis of biochar (Table 2), its application at the rate of $15 \mathrm{t} \mathrm{ha}^{-1}$ was expected to contribute to additional $\mathrm{N}$, available $\mathrm{P}$ and exchangeable $\mathrm{K}$ in the soil for at least one production period (Table 5). It was thus expected that soil $\mathrm{N}, \mathrm{P}, \mathrm{K}$ contents of plots receiving $\mathrm{CCB}$ and soil $\mathrm{P}, \mathrm{K}$ and $\mathrm{Ca}$ of plots receiving $\mathrm{EB}$ will be different from that of control plots. This was not the case, 6 and 12 months after both types of biochar application (Table 6). This could be due to one of the following: rapid uptake by plants during the first production, leaching or sorption on biochar. Soil N and P contents were significantly higher in FR plots compared to FP (Table 6), probably because added NPK fertilizer was buried in ridges, while it was mixed in the FP tillage mode. Soil available $P$ remains constant after biochar addition; this was also observed in acidic soils in other studies (Chintala et al. 2014; Schneider and Haderlein 2016; Zhang et al. 2016). A potential reason could be the fixation of $\mathrm{P}$ by $\mathrm{Al}$, given the relative low soil $\mathrm{pH}$. Soil exchangeable $\mathrm{K}$ and $\mathrm{Na}$ were significantly lower at the end of the second production period compared to the end of first, probably due to nutrient uptake by maize plants. Similarly, Steiner et al. (2007) did not observe greater $\mathrm{K}$ availability after one cropping season when wood biochar was added to a Brazilian Amazon oxisol at the rate of $11 \mathrm{tha}^{-1}$.

Both biochars interacted positively with production period to increase soil $\mathrm{OC}$ and $\mathrm{C} / \mathrm{N}$ ratio (Tables 2, 6). This is explained by the high OC content of biochar and the effect of mineralization. The relatively high content of graphitic-like carbon (Table 2) is also an indicator that applied biochar will remain stable for a longer period in these soils. Straw also contributed significantly to improve soil OC; this increase was more important during the second production period, likely due to straw mineralization with time. In summary, the biochar treatment positively affected soil $\mathrm{pH}$ and soil $\mathrm{OC}$, both tillage mode and production period also affected several soil chemical variables.

Table 5 Equivalent rate for biochar nutrient and carbon supply, maize needs and recommended fertilizer application rate

\begin{tabular}{|c|c|c|c|c|c|c|}
\hline Parameter & Units & $\begin{array}{l}\mathrm{CCB}^{\mathrm{a}} \text { (applied at } \\
15 \mathrm{t} \mathrm{ha}^{-1} \text { ) }\end{array}$ & $\begin{array}{l}\mathrm{EB}^{\mathrm{a}} \text { (applied at } \\
15 \mathrm{t} \mathrm{ha}^{-1} \text { ) }\end{array}$ & $\begin{array}{l}\text { Recommended local mineral fertilization } \\
\left(200 \mathrm{~kg} \mathrm{ha}^{-1} \mathrm{NPK}+100 \mathrm{~kg} \mathrm{ha}^{-1} \mathrm{~N}\right)\end{array}$ & $\begin{array}{l}\text { Maize needs for } \\
6 \mathrm{tha}^{-1 \mathrm{~b}}\end{array}$ & $\begin{array}{l}\text { Maize needs } \\
\text { for } 3 \mathrm{tha}^{-1 \mathrm{~b}}\end{array}$ \\
\hline Nitrogen & $\mathrm{kg} \mathrm{ha}^{-1}$ & 132 & 71 & 86 & 120 & 72 \\
\hline Phosphorus & $\mathrm{kg} \mathrm{ha}^{-1}$ & 27 & 25 & 9 & 22 & 16 \\
\hline Potassium & $\mathrm{kg} \mathrm{ha}^{-1}$ & 155 & 44 & 17 & 20 & 45 \\
\hline Calcium & $\mathrm{kg} \mathrm{ha}^{-1}$ & 5 & 86 & - & 24 & - \\
\hline Magnesium & $\mathrm{kg} \mathrm{ha}^{-1}$ & 5 & 6 & - & 25 & - \\
\hline Sodium & $\mathrm{kg} \mathrm{ha}^{-1}$ & 3 & 6 & - & 15 & 5 \\
\hline Organic carbon & $\mathrm{kg} \mathrm{ha}^{-1}$ & 4455 & 4170 & - & - & - \\
\hline
\end{tabular}

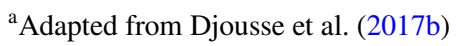

${ }^{\mathrm{b}}$ Adapted from FAO et al. (2003) 
Table 6 Analysis of variance for soil chemical parameters (degree of freedom and $p$ values)

\begin{tabular}{|c|c|c|c|c|c|c|c|c|c|}
\hline Parameters & $\mathrm{DF}$ & $\mathrm{N}$ & $\mathrm{P}$ & $\mathrm{K}$ & $\mathrm{Na}$ & CEC & $\mathrm{EC}$ & $\mathrm{pH}$ water & $\mathrm{OC}$ \\
\hline \multicolumn{10}{|l|}{ Treatments versus control } \\
\hline Production period (PP) & 1 & 0.25 & $<0.0001$ & $<0.0001$ & $<0.0001$ & 0.12 & $<0.0001$ & 0.19 & 0.0001 \\
\hline Treatment $(\mathrm{T})$ & 4 & 0.11 & 0.51 & 0.64 & 0.36 & 0.95 & 0.12 & 0.0001 & 0.01 \\
\hline $\mathrm{T} \times \mathrm{PP}$ & 4 & 0.49 & 0.30 & 0.46 & 0.36 & 0.96 & 0.46 & 0.85 & 0.31 \\
\hline Soil tillage mode (STM) & 1 & 0.03 & 0.02 & 0.27 & 0.11 & 0.43 & 0.15 & 0.67 & 0.77 \\
\hline $\mathrm{STM} \times \mathrm{PP}$ & 1 & 0.56 & 0.01 & 0.60 & 0.59 & 0.45 & 0.56 & 0.69 & 0.44 \\
\hline $\mathrm{T} \times \mathrm{STM}$ & 4 & 0.27 & 0.05 & 0.67 & 0.74 & 0.98 & 0.06 & 0.37 & 0.72 \\
\hline $\mathrm{T} \times \mathrm{STM} \times \mathrm{PP}$ & 4 & 0.43 & 0.13 & 0.64 & 0.85 & 1.00 & 0.75 & 0.24 & 0.02 \\
\hline \multicolumn{10}{|l|}{ In between treatments } \\
\hline Biochar type (BT) & 1 & 0.12 & 0.08 & 0.18 & 0.07 & 0.71 & 0.42 & 0.0001 & 0.68 \\
\hline $\mathrm{PP}$ & 1 & 0.38 & $<0.00$ & $<0.00$ & $<0.00$ & 0.16 & $<0.0001$ & 0.42 & 0.02 \\
\hline $\mathrm{BT} \times \mathrm{PP}$ & 1 & 0.12 & $\mathbf{0 . 0 3}$ & 0.14 & 0.12 & 0.59 & 0.73 & 0.45 & 0.66 \\
\hline STM & 1 & 0.23 & 0.0001 & 0.47 & 0.26 & 0.29 & 0.04 & 0.48 & 0.56 \\
\hline $\mathrm{BT} \times \mathrm{STM}$ & 1 & 0.95 & 0.08 & 0.74 & 0.88 & 0.75 & 0.10 & 0.36 & 0.37 \\
\hline $\mathrm{STM} \times \mathrm{PP}$ & 1 & 0.26 & 0.0001 & 0.22 & 0.47 & 0.45 & 0.24 & 0.74 & 0.84 \\
\hline $\mathrm{BT} \times \mathrm{STM} \times \mathrm{PP}$ & 1 & 0.14 & 0.06 & 0.80 & 0.67 & 0.62 & 0.79 & 0.77 & 0.22 \\
\hline Straw (S) & 1 & 0.12 & 0.39 & 0.37 & 0.47 & 0.93 & 0.58 & 0.97 & 0.03 \\
\hline $\mathrm{BT} \times \mathrm{S}$ & 1 & 0.74 & 0.89 & 0.74 & 0.88 & 0.82 & 0.36 & 0.60 & 0.96 \\
\hline $\mathrm{S} \times \mathrm{PP}$ & 1 & 0.46 & 0.62 & 0.41 & 0.67 & 0.75 & 0.51 & 0.97 & 0.11 \\
\hline $\mathrm{BT} \times \mathrm{S} \times \mathrm{PP}$ & 1 & 0.97 & 0.82 & 0.68 & 0.67 & 0.68 & 0.77 & 0.67 & 0.36 \\
\hline $\mathrm{S} \times \mathrm{STM}$ & 1 & 0.10 & 0.06 & 0.74 & 0.32 & 0.81 & 0.0001 & 0.54 & 0.87 \\
\hline $\mathrm{BT} \times \mathrm{S} \times \mathrm{STM}$ & 1 & 0.19 & 0.55 & 0.37 & 0.47 & 0.88 & 0.37 & 0.20 & 0.81 \\
\hline $\mathrm{S} \times \mathrm{STM} \times \mathrm{PP}$ & 1 & 0.82 & 0.12 & 0.68 & 0.47 & 0.99 & 0.07 & 0.97 & 0.39 \\
\hline
\end{tabular}

NB: $D F$ degree of freedom, $N$ total nitrogen, $P$ exchangeable phosphorus; $K$ exchangeable potassium, $N a$ exchangeable sodium, $C E C$ cation exchange capacity, $E C$ electrical conductivity, $O C$ organic carbon

Significant $p$ values are in bold characters

\section{Agronomic implications of the study}

The selected application rate of $15 \mathrm{tha}^{-1}$ of biochar made from Eucalyptus bark and corncob residues $\left(300{ }^{\circ} \mathrm{C}\right) \mathrm{did}$ not have an important influence on soil physical properties, but did have an effect on chemical properties, at the end of 12 months and two production periods of maize. The obtained results have the following implications for farmers intending to use biochar for soil improvement.

- There is no drawback in using these biochars in oxisols under either tillage mode;

- The biochar did not affect water retention in these high porosity, low density and well-drained oxisols; biochar with a different particle size distribution might exhibit a different response;

- The tested biochars may be used to improve soil $\mathrm{pH}$ and OC, with both studied tillage modes;

- The furrow and ridges tillage mode contributed to better storage of soil total $\mathrm{N}$ and higher exchangeable $\mathrm{K}$, compared to flat ploughing;
- The use of straw instead of biochars in furrow and ridges mode did not show any advantage as far as soil water retention is concerned. Given the reported positive side effects of biochar, mainly its reported $\mathrm{C}$ sequestration potential (Wang et al. 2016), we recommend that straw be pyrolysed and the resulting biochar incorporated into soil instead of burying straw (as is actually done in furrow and ridges tillage mode).

\section{Conclusion}

Biochars made from eucalyptus tree bark and corncobs in a retort kiln at $300{ }^{\circ} \mathrm{C}$ and applied at the rate of $15 \mathrm{t} \mathrm{ha}^{-1}$ on a clay loam soil in Cameroon (oxisol), significantly increased soil $\mathrm{pH}$ and organic carbon. Both biochars marginally increased $\theta_{\mathrm{r}}, \theta_{\mathrm{s}}$ and AWC values of AWC being higher in flat plot soil tillage mode compared to furrow and ridges tillage mode. Total soil porosity was lower, and water retention was higher in the second production period, compared to the first. The use of biochar at higher application rate and the 
assessment of the longer-term fate of carbon from biochar could also constitute future research studies on these oxisols, in order to understand the potential for carbon sequestration.

Acknowledgements The authors express their gratitude to the "Programme Élargi de Formation en Gestion des Ressources Naturelles dans le Bassin du Congo" (PEFOGRN_BC), Réseau des institutions de formation forestière et environnementale d'Afrique centrale (RIFFEAC) and the "Fonds pour les Forêts du Bassin du Congo" (FFBC) for their financial and logistical support. We also thank the laboratories of soil physics and soil chemistry of the FASA at University of Dschang and the soil and environment laboratory of the FFGG at Universite Laval, in particular Alain Brousseau, for their assistance in soil analysis.

Open Access This article is distributed under the terms of the Creative Commons Attribution 4.0 International License (http://creativeco mmons.org/licenses/by/4.0/), which permits unrestricted use, distribution, and reproduction in any medium, provided you give appropriate credit to the original author(s) and the source, provide a link to the Creative Commons license, and indicate if changes were made.

\section{References}

Allaire SE, Parent LE (2004) Physical properties of granular organicbased fertilisers, part 2. Biosyst Eng 87:225-236. https://doi. org/10.1016/j.biosystemseng.2003.09.007

ASTM (1990) ASTM D1762-84: standard method for chemical analysis of wood charcoal. ASTM Int 1-2

ASTM (2002) ASTM D4373-02: standard test method for rapid determination of carbonate content of soils. ASTM Int 2:1-5. https:// doi.org/10.1520/D4373-02R07

ASTM (2008) ASTM-D5093: standard test method for field measurement of infiltration rate using double-ring infiltrometer with sealed-inner ring. ASTM Int 1-7. https://doi.org/10.1520/d5093 $-02 \mathrm{r} 08.2$

ASTM (2009) ASTM-D7263: standard test methods for laboratory determination of density (unit weight) of soil specimens. ASTM Int i:1-7. https://doi.org/10.1520/D7263-09.2

ASTM (2010) ASTM-D2862-10: standard test method for particle size distribution of granular activated carbon. ASTM Int i:1-6. https:// doi.org/10.1520/D2862-10.2

ASTM (2014) ASTM-D4959-07: standard test method for determination of water (moisture) content of soil by direct. ASTM Int 1-6. https://doi.org/10.1520/d4959-07

ASTM (2015) ASTM B923-10: standard test method for metal powder skeletal density by helium or nitrogen. ASTM Int 10-13. https:// doi.org/10.1520/b0923-10.2

Atkinson CJ, Fitzgerald JD, Hipps NA (2010) Potential mechanisms for achieving agricultural benefits from biochar application to temperate soils: a review. Plant Soil 337:1-18. https://doi.org/10.1007/ s11104-010-0464-5

Baligar VC, Bennett OL (1986) Outlook on fertilizer use efficiency in the tropics. Fertil Res 10:83-96

Barbosa de Sousa AM, Soares Santos RR, Gehring C (2014) Charcoal in Amazonian paddy soil-nutrient availability, rice growth and methane emissions. J Plant Nutr Soil Sci 177:39-47. https://doi. org/10.1002/jpln.201300088

Bargmann Inge, Martens R, Rillig Matthias C, Kruse A, Kücke M (2014) Hydrochar amendment promotes microbial immobilization of mineral nitrogen. J Plant Nutr Soil Sci 177:59-67. https://doi. org/10.1002/jpln.201300154
Barnes Rebecca T, Gallagher Morgan E, Masiello CA, Liu Zuolin, Dugan B (2014) Biochar-induced changes in soil hydraulic conductivity and dissolved nutrient fluxes constrained by laboratory experiments. PLoS ONE 9:1-9. https://doi.org/10.1371/journ al.pone. 0108340

Bhattarai Bishwoyog, Neupane Jasmine, Dhakal SP, Gnyawali B (2015) Effect of biochar from different origin on physio-chemical properties of soil and yield of garden pea (Pisum sativum L.) at Paklihawa, Rupandehi, Nepal. World J Agric Res 3:129-138. https:// doi.org/10.12691/wjar-3-4-3

Biederman LA, Stanley Harpole W (2013) Biochar and its effects on plant productivity and nutrient cycling: a meta-analysis. GCB Bioenergy 5:202-214. https://doi.org/10.1111/gcbb.12037

Brewer CE, Brown RCLD (2012) Biochar characterization and engineering. Doctoral Dissertations, Iowa State University

Burrell Leigh D, Zehetner F, Rampazzo Nicola, Wimmer Bernhard, Soja G (2016) Long-term effects of biochar on soil physical properties. Geoderma 282:96-102. https://doi.org/10.1016/j.geode rma.2016.07.019

Butnan Somchai, Deenik Jonathan L, Toomsan B, Antal Michael J, Vityakon P (2015) Biochar characteristics and application rates affecting corn growth and properties of soils contrasting in texture and mineralogy. Geoderma 237-238:105-116. https://doi. org/10.1016/j.geoderma.2014.08.010

Castellini M, Giglio L, Niedda M, Palumbo AD, Ventrella D (2015) Impact of biochar addition on the physical and hydraulic properties of a clay soil. Soil Tillage Res 154:1-13. https://doi. org/10.1016/j.still.2015.06.016

CEAEQ (Centre d'expertise en analyse environnementale du Québec) (2015) Protocole pour la validation d'une méthode d'analyse en chimie. Quebec

Chintala R, McDonald LM, Bryan WB (2012) Effect of soil water and nutrients on productivity of Kentucky bluegrass system in acidic soils. J Plant Nutr 35:288-303. https://doi.org/10.1080/01904 167.2012.636131

Chintala Rajesh, Mollinedo Javier, Schumacher TE, Malo Douglas D, Julson JL (2014) Effect of biochar on chemical properties of acidic soil. Arch Agron Soil Sci 60:393-404. https://doi. org/10.1080/03650340.2013.789870

Clough T, Condron L, Kammann C, Müller C (2013) A review of biochar and soil nitrogen dynamics. Agronomy 3:275-293. https ://doi.org/10.3390/agronomy3020275

Craswell ET, Vlek PLG (2013) Mining of nutrients in african soils due to agricultural intensification. In: Lal R, Stewart BA (eds) Principles of sustainable soil management in agroecosystems. CRC Press, New York, pp 401-421

DeLuca TH, MacKenzie MD, Gundale MJ (2009) Biochar effects on soil nutrient transformations. In: Lehmann J, Joseph S (eds) Biochar for environmental management science and technology. Earthscan, London, pp 251-270

Devereux RC, Sturrock CJ, Mooney SJ (2012) The effects of biochar on soil physical properties and winter wheat growth. Earth Environ Sci Trans R Soc Edinburgh 103:13-18. https://doi.org/10.1017/ S1755691012000011

Djousse KBM, Allaire SE, Munson AD (2017a) Quality of biochars made from eucalyptus tree bark and corncob using a pilot-scale retort Kiln. Waste Biomass Valorization 4:1-11. https://doi. org/10.1007/s12649-017-9884-2

Djousse KBM, Allaire SE, Alison MD (2017b) Biochar improves maize nutritional status and yield under two soil tillage modes. Int J Sci Res 6(10):470-475. https://doi.org/10.21275/ART20176493

Downie AACPM (2009) Physical properties of biochar. Biochar for environmental management—science and technology. Lehmann, London, pp 13-32

Durner W, Flühler H (2005) Soil hydraulic properties. Encycl Hydrol Sci 74:1-17. https://doi.org/10.1002/0470848944.hsa077c 
Durval DN, Donald RN, Jan WH, Klaus RB, Oliveira O, Santos LPP (2001) SWRC, version 3.00 beta. Piracicaba, SP. http://docentes. esalq.usp.br/dourado/. Accessed Feb 2016

Eastman CM (2011) Soil physical characteristics of an Aeric Ochraqualf amended with Biochar. M.Sc. Diss thesis, Ohio State University

FAO (2016) FAO—Water development and management unit—crop water information: maize. http://www.fao.org/nr/water/cropinfo_ sunflower.html. Accessed 16 Apr 2017

FAO, IFA, IMPHOS (2003) Les engrais et leurs applications. FAO, Rome

Flint LE, Flint AL (2002) Porosity. In: Dane JH, Topp GC (eds) Methods of soil analysis. Soil Science Society of America, Madison, WI, pp 241-254

Gaskin JW, Speir A, Morris LM, Ogden L, Harris K, Lee D, Das KC (2007) Potential for pyrolysis char to affect soil moisture and nutrient status of a loamy sand soil. In: Proceedings of the 2007 Georgia water resources conference, March 27-29, the University of Georgia. University of Georgia, Georgia, pp 1-3

Gee GW, Bauder JW (1986) Particle size analysis in methods of soil analysis Part 1, 2nd edn. Madison, Wisconsin, pp 383-409

Githinji L (2014) Effect of biochar application rate on soil physical and hydraulic properties of a sandy loam. Arch Agron Soil Sci 60:457-470. https://doi.org/10.1080/03650340.2013.821698

Glaser B, Lehmann J, Zech W (2002) Ameliorating physical and chemical properties of highly weathered soils in the tropics with charcoal-a review. Biol Fertil Soils 35:219-230. https://doi. org/10.1007/s00374-002-0466-4

Hadi-Akbar Basri M, Junejo N, Abdu A, Abdul Hamid H, Ashadie Kusno M (2013) Elevation and variability of acidic sandy soil $\mathrm{pH}$ : amended with conditioner, activator, organic and inorganic fertilizers. Afr J Agric Res 8:4020-4024. https://doi.org/10.5897/ AJAR2013.1295

Hardie Marcus, Clothier B, Bound Sally, Oliver Garth, Close D (2013) Does biochar influence soil physical properties and soil water availability? Plant Soil 376:347-361. https://doi.org/10.1007/ s11104-013-1980-x

Herath HMSK, Camps-Arbestain Marta, Hedley M (2013) Effect of biochar on soil physical properties in two contrasting soils: an Alfisol and an Andisol. Geoderma 209-210:188-197. https://doi. org/10.1016/j.geoderma.2013.06.016

Hillel D (2004) Introduction to environmental soil physics. Academic Press, Cambridge

Hossain MF, Chen W, Zhang Y (2015) Bulk density of mineral and organic soils in the Canada' $s$ arctic and sub-arctic. Inf Process Agric 2:183-190. https://doi.org/10.1016/j.inpa.2015.09.001

Ippolito JA, Stromberger ME, Lentz RD, Dungan RS (2014) Hardwood biochar influences calcareous soil physicochemical and microbiological status. J Environ Qual 43:681-689. https://doi. org/10.2134/jeq2013.08.0324

ISO 5311:1992 (1992) Engrais-Détermination de la masse volumique après tassement. In: Online Brows. Platf. https://www.iso.org/obp/ ui/\#iso:std:iso:5311:ed-3:v1:fr. Accessed 2 Mar 2015

ISO 9686:2 (2006) Direct reduced iron-determination of carbon and/or sulfur-high-frequency combustion method with infrared measurement. In: ISO. https://www.iso.org/obp/ ui/\#iso:std:iso:9686:ed-2:v1:en. Accessed 5 Jan 2017

Jeffery Simon, Meinders Marcel BJ, Stoof Cathelijne R, Bezemer T Martijn, van de Voorde Tess FJ, Mommer Liesje, van Groenigen JW (2015) Biochar application does not improve the soil hydrological function of a sandy soil. Geoderma 251-252:47-54. https ://doi.org/10.1016/j.geoderma.2015.03.022

Jones BEH, Haynes RJ, Phillips IR (2010) Effect of amendment of bauxite processing sand with organic materials on its chemical, physical and microbial properties. J Environ Manag 91:22812288. https://doi.org/10.1016/j.jenvman.2010.06.013

Karhu K, Mattila T, Bergström I, Regina K (2011) Biochar addition to agricultural soil increased $\mathrm{CH} 4$ uptake and water holding capacity-results from a short-term pilot field study. Agric Ecosyst Environ 140:309-313. https://doi.org/10.1016/j.agee.2010.12.005

Ker A (1995) Farming systems of the African savanna, a Continent in Crisis. IDRC, Ottawa, ON

Kimetu JM, Lehmann J (2010) Stability and stabilization of biochar and green manure in soil with different organic carbon contents. Aust J Soil Res 48:577-585

Laird DA, Fleming P, Davis DD, Horton R, Wang B, Karlen DL (2010a) Impact of biochar amendments on the quality of a typical midwestern agricultural soil. Geoderma 158:443-449. https ://doi.org/10.1016/j.geoderma.2010.05.013

Laird David, Fleming Pierce, Wang Baiqun, Horton Robert, Karlen D (2010b) Biochar impact on nutrient leaching from a midwestern agricultural soil. Geoderma 158:436-442. https://doi. org/10.1016/j.geoderma.2010.05.012

LECO (2009) Determinator instruction manual SC 632 Carbon/Sulfur, Version $1.4 \mathrm{X}$

Major J, Rondon M, Molina D, Riha SJ, Lehmann J (2010) Maize yield and nutrition during 4 years after biochar application to a Colombian savanna oxisol. Plant Soil 333:117-128

Major J, Rondon M, Molina Diego, Riha Susan J, Lehmann J (2011) Nutrient leaching in a Colombian savanna Oxisol amended with biochar. J Environ Qual 41:1076-1086. https://doi.org/10.2134/ jeq2011.0128

Mann CC (2002) The real dirt on rainforest fertility. Adv Sci 297:920-923

Meng CP, Husni A, Hanif M, Wahid SA (2014) Short-term field decomposition and physico-chemical transformation of Jatropha pod biochar in acidic mineral soil. Soil Sci 4:226-234. https://doi. org/10.4236/ojss.2014.47025

Mohanty BP, Mousli Z (2000) Saturated hydraulic conductivity and soil water retention properties across a soil-slope transition. Water Resour Res 36:3311-3324. https://doi.org/10.1029/2000WR9002 16

Mukherjee A, Zimmerman AR, Harris W (2011) Surface chemistry variations among a series of laboratory-produced biochars. Geoderma 163:247-255. https://doi.org/10.1016/j.geode rma.2011.04.021

Novak Jeffrey M, Busscher Warren J, Laird David L, Ahmedna Mohamed, Watts Don W, Niandou MAS (2009) Impact of biochar amendment on fertility of a southeastern coastal plain soil. Soil Sci 174:105-112. https://doi.org/10.1097/SS.0b013e3181981d9a

Ojeda Gerardo, Mattana Stefania, Ävila Anna, Alcañiz Josep Maria, Volkmann M, Bachmann J (2015) Are soil-water functions affected by biochar application? Geoderma 249-250:1-11. https ://doi.org/10.1016/j.geoderma.2015.02.014

Omondi Morris Oduor, Xia Xin, Nahayo Alphonse, Liu X, Korai Punhoon Khan, Pan G (2016) Quantification of biochar effects on soil hydrological properties using meta-analysis of literature data. Geoderma 274:28-34. https://doi.org/10.1016/j.geode rma.2016.03.029

Ouyang L, Wang F, Tang J, Yu L, Zhang R (2013) Effects of biochar amendment on soil aggregates and hydraulic properties. J Plant Nutr Soil Sci 13:991-1002. https://doi.org/10.2136/sssaj 2012.0180

Pandian K, Subramaniayan P, Gnasekaran P, Chitraputhirapillai S (2016) Effect of biochar amendment on soil physical, chemical and biological properties and groundnut yield in rainfed Alfisol of semi-arid tropics. Arch Agron Soil Sci 62:1293-1310. https:// doi.org/10.1080/03650340.2016.1139086 
Parvage Mohammed Masud, Ulén Barbro, Eriksson Jan, Strock Jeffery, Kirchmann H (2013) Phosphorus availability in soils amended with wheat residue char. Biol Fertil Soils 49:245-250. https://doi. org/10.1007/s00374-012-0746-6

Pauwels J, Van Ranst E, Verloo M, Mvondo Ze A (1992) Manuel de Laboratoire de Pédologie-méthodes d'analyses de sols et de plantes; equipment et gestion des stocks de verrerie et de produits chimiques. Publications Agricoles nr. 28, A.G.C.D. Bruxelles, Belgium

Prommer Judith, Wanek Wolfgang, Hofhansl Florian, Trojan Daniela, Offre P, Urich Tim, Schleper C, Sassmann Stefan, Kitzler Barbara, Soja Gerhard, Hood-Nowotny RC (2014) Biochar decelerates soil organic nitrogen cycling but stimulates soil nitrification in a temperate arable field trial. PLoS ONE 9:1-16. https://doi. org/10.1371/journal.pone.0086388

Qian T, Zhang X, Hu J, Jiang H (2013) Effects of environmental conditions on the release of phosphorus from biochar. Chemosphere 93:2069-2075

Rajkovich Shelby, Enders Akio, Hanley Kelly, Hyland Charles, Zimmerman Andrew R, Lehmann J (2011) Corn growth and nitrogen nutrition after additions of biochars with varying properties to a temperate soil. Biol Fertil Soils 48:271-284. https://doi. org/10.1007/s00374-011-0624-7

Reverchon Frédérique, Flicker Robert C, Yang Hong, Yan Guijun, Xu Zhihong, Chen Chengrong, Bai Hosseini, Shahla Zhang D (2014) Changes in a soil-plant system under different biochar feedstocks and application rates. Biol Fertil Soils 50:275-283. https://doi. org/10.1007/s00374-013-0850-2

Rogovska N, Laird DA, Karlen DL (2016) Corn and soil response to biochar application and stover harvest. Field Crops Res 187:96106. https://doi.org/10.1016/j.fcr.2015.12.013

Rondon MA, Lehmann J, Ramírez J, Hurtado M (2007) Biological nitrogen fixation by common beans (Phaseolus vulgaris L.) increases with biochar additions. Biol Fertil Soils 43:699-708. https://doi.org/10.1007/s00374-006-0152-z

Ross D, Kettering Q (2011) Recommended methods for determining soil cation exchange capacity. Chapter 9 . In: Recommended soil testing procedures for the Northeastern United States. Cooperative Bulletin No. 493 75-86

Rühlmann J, Körschens M, Graefe J (2006) A new approach to calculate the particle density of soils considering properties of the soil organic matter and the mineral matrix. Geoderma 130:272-283. https://doi.org/10.1016/j.geoderma.2005.01.024

Sanchez PA, Villachica JH, Bandy DE (1983) Soil fertility dynamics after clearing a tropical rainforest in Peru. Soil Sci Soc Am J 47:1171-1178. https://doi.org/10.2136/sssaj1983.0361599500 $4700060023 \mathrm{x}$

Sarki Asadullah, Mirjat Muhammad Saffar, Mahessar Ali Asghar, Kori Shafi Muhammad, Qureshi AL (2014) Determination of saturated hydraulic conductivity of different soil texture materials. J Agric Vet Sci 7:56-62

Schneider F, Haderlein SB (2016) Potential effects of biochar on the availability of phosphorus-mechanistic insights. Geoderma 277:83-90. https://doi.org/10.1016/j.geoderma.2016.05.007

Sohi S, Lopez-capel E, Krull E, Bol R (2009) Biochar, climate change and soil: a review to guide future research. CSIRO L Water Sci 05(09):1-64. https://doi.org/10.1139/Z03-132

Steiner Christoph, Teixeira Wenceslau G, Lehmann Johannes, Nehls Thomas, MacÊdo De, Vasconcelos Jeferson Luis, Blum Winfried E H, Zech W (2007) Long term effects of manure, charcoal and mineral fertilization on crop production and fertility on a highly weathered Central Amazonian upland soil. Plant Soil 291:275290. https://doi.org/10.1007/s11104-007-9193-9
Ueckert DN, Whigham TL, Spears BM (1978) Effect of soil burning on infiltration, sediment, and other soil properties in a mesquitetobosagrass community. J Range Manage 31(6):420-425

Unger R, Killorn R, Brewer C (2011) Effects of soil application of different biochars on selected soil chemical properties. Commun Soil Sci Plant Anal 42:2310-2321. https://doi.org/10.1080/00103 624.2011 .605489

USDA (2014) Keys to soil taxonomy, 12th edn. USDA, Washington, DC

Uzoma KC, Inoue M, Andry H, Zahoor A, Nishihara E (2011) Influence of biochar application on sandy soil hydraulic properties and nutrient. J Food Agric Environ 9:1137-1143

Ventura Francesca, Salvatorelli Fiorenzo, Piana Stefano, Pieri Linda, Pisa PR (2013) The effects of biochar on the physical properties of bare soil. Earth Environ Sci Trans R Soc Edinburgh 103:5-11. https://doi.org/10.1017/S1755691012000059

Verheijen F, Jeffery S, Bastos AC, Van der Velde M, Diasfas I (2010) Biochar application to soils: a critical scientific review of effects on soil properties, processes and functions. EUR $24099 \mathrm{EN}$, Office for the Official Publications of the European Communities, Luxembourg

Wang J, Xiong Z, Kuzyakov Y (2016) Biochar stability in soil: metaanalysis of decomposition and priming effects. GCB Bioenergy $8: 512-523$

Widowati W, Asnah A (2014) Biochar effect at potassium fertilizer and dosage leaching potassium for two-corn planting season. AGRIVITA J Agric Sci 36:65-71

Xu G, Sun J, Shao H, Chang SX (2014) Biochar had effects on phosphorus sorption and desorption in three soils with differing acidity. Ecol Eng 62:54-60. https://doi.org/10.1016/j.ecoleng.2013.10.027

Xu G, Zhang Y, Shao H, Sun J (2016a) Pyrolysis temperature affects phosphorus transformation in biochar: chemical fractionation and 31P NMR analysis. Sci Total Environ 569-570:65-72. https://doi. org/10.1016/j.scitotenv.2016.06.081

Xu G, Zhang Y, Sun J, Shao H (2016b) Negative interactive effects between biochar and phosphorus fertilization on phosphorus availability and plant yield in saline sodic soil. Sci Total Environ 568:910-915. https://doi.org/10.1016/j.scitotenv.2016.06.079

Yeboah E, Ofori P, Quansah GW, Dugan E, Sohi SP (2009) Improving soil productivity through biochar amendments to soils. Afr J Environ Sci Technol 3:34-41

Yu O-Y, Raichle B, Sink S (2013) Impact of biochar on the water holding capacity of loamy sand soil. Int J Energy Environ Eng 4:1-9. https://doi.org/10.1186/2251-6832-4-44

Zhang Hanzhi, Chen Chengrong, Gray Evan M, Boyd Sue E, Yang Hong, Zhang D (2016) Roles of biochar in improving phosphorus availability in soils: a phosphate adsorbent and a source of available phosphorus. Geoderma 276:1-6. https://doi.org/10.1016/j. geoderma.2016.04.020

Zheng Hao, Wang Zhenyu, Deng Xia, Herbert Stephen, Xing B (2013) Impacts of adding biochar on nitrogen retention and bioavailability in agricultural soil. Geoderma 206:32-39. https://doi. org/10.1016/j.geoderma.2013.04.018

Zong Y, Xiao Q, Lu S (2016) Acidity, water retention, and mechanical physical quality of a strongly acidic Ultisol amended with biochars derived from different feedstocks. J Soils Sediments 16:177-190. https://doi.org/10.1007/s11368-015-1187-2

Publisher's Note Springer Nature remains neutral with regard to jurisdictional claims in published maps and institutional affiliations. 